\title{
Evaluasi Kualitas dan Kuantitas Lumpur Alum dari Instalasi Pengolahan Air Minum Citayam
}

\section{Evaluation of Alum Sludge Quality and Quantity from Citayam Water Treatment Plant}

\author{
SANDYANTO ADITYOSULINDRO, NURUL H. ROCHMATIA, DJOKO M. HARTONO, SETYO S. \\ MOERSIDIK
}

\author{
Universitas Indonesia, Program Studi Teknik Lingkungan, Departemen Teknik Sipil \\ Departemen Teknik Sipill, Fakultas Teknik, Kampus Universitas Indonesia, Depok 16424 \\ Email: adityosulindro@eng.ui.ac.id
}

\begin{abstract}
Water treatment plants (WTPs) produces residues in the form of alum sludge during the treatment process. In Indonesia, due to various techno-economic constraints, some WTPs are not equipped by sludge treatment systems, so the generated alum sludge is discharged directly into water bodies without appropriate treatment. This condition may pollute water bodies because alum sludge contains various contaminants such as solid particles, organic compounds, inorganic metals, aluminum, and pathogenic microorganisms. This study aims to evaluate the characteristics of alum sludge from aspects of quality and quantity, which is indispensable for the design of sludge treatment facilities. Citayam WTP (capacity of 120 L/s) in Depok City was chosen as a case study. The study was conducted in several stages as follows: (i) survey and sampling; (ii) quality analysis of alum sludge; (iii) estimation of sludge generation; and (iv) mass and volume balance analysis. Results of comparative analysis of alum sludge quality against the Regulation of Minister of Environment of Indonesia 5/2014 shows alum sludge from flocculation units meets quality standards. In contrast, alum sludge from sedimentation and filter units were exceeded for TSS, COD, and Total Coliform parameters. Quantity-wise, the estimation of sludge generation by theoretical and empirical methods was found to be 1,898 $\mathrm{kg} /$ day and $4,854 \mathrm{~kg} /$ day. Analysis of mass and volume balance using STAN software indicates that the theoretical approach is quite representative, while the empirical method tends to be over-estimated.
\end{abstract}

Keywords: alum sludge, sludge quality, sludge generation, water treatment plant, case study

\begin{abstract}
ABSTRAK
Instalasi pengolahan air (IPA) dalam proses pengolahannya akan menghasilkan residu berupa lumpur alum. Di Indonesia, akibat berbagai kendala tekno-ekonomis, masih terdapat IPA yang belum memiliki sistem pengolahan lumpur alum sehingga langsung dibuang ke badan air tanpa pengolahan. Kondisi ini berpotensi mencemari badan air karena lumpur alum mengandung berbagai kontaminan seperti partikel padat, senyawa organik, inorganik, logam aluminium serta mikroorganisme patogen. Penelitian ini bertujuan untuk mengevaluasi karakteristik lumpur alum dari aspek kualitas dan kuantitas yang merupakan informasi penting dalam perancangan sistem pengolahan lumpur. IPA Citayam (Kapasitas 120 L/detik) di Kota Depok dipilih sebagai objek studi. Penelitian dilakukan dalam beberapa tahapan yakni survei dan sampling, analisis kualitas lumpur alum, estimasi timbulan lumpur, dan analisis neraca massa dan volume. Hasil perbandingan analisis kualitas lumpur alum terhadap PermenLH 5/2014 menunjukan lumpur alum dari unit flokulasi memenuhi baku mutu sedangkan lumpur alum dari unit sedimentasi dan filter melebihi baku mutu lingkungan untuk parameter TSS, COD dan Total Koliform. Dari aspek kuantitas, estimasi timbulan lumpur yang dilakukan dengan metode teoritik dan empirik berturut-turut sebesar $1.898 \mathrm{~kg} / \mathrm{hari}$ dan $4.854 \mathrm{~kg} / \mathrm{hari}$. Analisis neraca massa dan volume menggunakan software STAN mengindikasikan bahwa metode teoritik cukup representatif, sedangkan perhitungan dengan metode empirik cenderung menjadi over-estimasi.
\end{abstract}

Kata kunci: lumpur alum, kualitas lumpur, timbulan lumpur, instalasi pengolahan air, studi kasus 


\section{PENDAHULUAN}

Air minum merupakan sesuatu yang digunakan manusia untuk memenuhi kebutuhan sehari-hari khususnya untuk konsumsi minum, mandi, dan mencuci. Kebutuhan air minum akan meningkat seiring dengan adanya pertambahan jumlah penduduk. Penyediaan air minum di suatu kawasan dilakukan oleh Perusahaan Daerah Air Minum (PDAM) menggunakan instalasi pengolahan air (IPA) yang mengolah air baku menjadi air minum. Pengolahan air baku menjadi air minum dilakukan dengan kombinasi pengolahan fisik kimia seperti koagulasi, flokulasi, sedimentasi dan filtrasi yang membutuhkan bahan kimia koagulan alum sulfat $\left(\mathrm{Al}_{2}\left(\mathrm{SO}_{4}\right)_{3}\right)$, sehingga menghasilkan residu pengolahan berupa lumpur alum. Berdasarkan literatur, total kuantitas timbulan lumpur di seluruh Inggris sekitar 180.000 ton lumpur kering/tahun atau sekitar $3,7 \mathrm{~kg}$ lumpur kering/kapita ${ }^{(1)}$. Di negara bagian Victoria, Australia, total biaya pengelolaan lumpur berkisar $\$ 6.2$ juta/tahun ${ }^{(2)}$. Residu lumpur dapat mengandung berbagai kontaminan seperti partikel padat, senyawa organik, inorganik, aluminium, serta mikroorganisme patogen ${ }^{(3)}$. Konsentrasi TSS yang tinggi pada lumpur alum dapat mengganggu penetrasi cahaya matahari dan oksigen ke dalam air serta menjadi carrier senyawa berbahaya seperti logam berat dan patogen $^{(4)}$. Selain itu, penambahan koagulan dalam proses pengolahan air juga menyebabkan lumpur alum mengandung logam aluminium yang pada konsentrasi tinggi bersifat toksik bagi manusia(5). Oleh karena itu, sebuah IPA idealnya dilengkapi dengan unit-unit pengolahan lumpur alum yang berfungsi untuk mereduksi kadar air dan patogen ${ }^{(6)}$.

Akan tetapi, pengelolaan lumpur alum ternyata masih menjadi tantangan besar di Indonesia. Salah satu contohnya adalah di IPA Cltayam Kota Depok yang merupakan objek studi penelitian ini, dimana lumpur residu pengolahan dialirkan langsung menuju badan air (Sungai Ciliwung) tanpa pengolahan. Tujuan penelitian ini adalah untuk mengevaluasi karakteristik lumpur dari aspek kualitas dan kuantitas yang merupakan informasi penting dalam perancangan sistem pengolahan lumpur di IPA.

\section{BAHAN DAN METODE}

\subsection{Metodologi Penelitian}

Penelitian ini termasuk ke dalam penelitian terapan yang mengaplikasikan prinsip sains dan keteknikan untuk mengevaluasi karakteristik lumpur alum dari aspek kualitas dan kuantitas di IPA Citayam. Penelitian dilakukan dalam beberapa tahapan sebagai berikut: (i) survei dan sampling; (ii) analisis kualitas lumpur alum; (iii) estimasi timbulan lumpur; (iv) analisis neraca massa dan volume.

\subsection{Deskripsi Singkat Objek Studi}

Instalasi Pengolahan Air (IPA) Citayam merupakan salah satu IPA di Kota Depok yang dikelola oleh PDAM Tirta Asasta. IPA Citayam mengolah air baku dari Sungai Ciliwung dengan kapasitas produksi sebesar 120 L/detik (10.368 $\mathrm{m}^{3} /$ hari). Sistem pengolahan air di IPA Citayam merupakan sistem konvensional yang disebut sebagai sistem Kedasih. Kedasih merupakan singkatan dari Keluaran Direktorat Air Bersih. IPA Kedasih pertama kali dikembangkan oleh Ir. Pudjastanto, CE, DEA dari Direktorat Air Bersih, Direktorat Cipta Karya Kementrian Pekerjaan Umum $^{(7)}$. Unit-unit pengolahan IPA Kedasih berupa koagulasi hidrolik (hydraulic coagulation) tipe terjunan, flokulasi hidrolik (hydraulic flocculation) tipe hexacoidal, sedimentasi dengan tube settler (clarifier with tube settler), filtrasi saringan pasir cepat (rapid sand filtration) dan klorinasi (chlorination). Koagulan yang digunakan adalah alum sulfat dengan dosis rata-rata $27 \mathrm{mg} / \mathrm{L}$.

IPA Citayam melayani kebutuhan air minum di Kelurahan Beji, Beji Timur, Kemiri Muka, Tanah Baru, Grogol, Meruyung, Depok Jaya, Pancoran Mas, Mampang, Rangkapan Jaya, Rangkapan Jaya Baru, Depok, dan Sawangan Baru. Persentase pelayanan Sistem Citayam ini secara administratif wilayah mencapai $2,27 \%$ dengan kehilangan air rata-rata $28,53 \%$.

Dalam proses produksinya, IPA Citayam menghasilkan residu berupa lumpur dari unit flokulasi, sedimentasi dan filtrasi. Pembuangan lumpur pada unit-unit tersebut dilakukan setiap 1-2 kali sehari melalui pipa pembuangan di setiap unit yang membuang lumpur ke saluran drainase yang bermuara di sebuah saluran yang menuju Sungai Ciliwung.

\subsection{Pengambilan Sampel}

Pengambilan sampel terdiri dari sampel air dan lumpur. Pengambilan sampel air dilakukan secara grab sampling di inlet unit koagulasi, outlet unit sedimentasi, dan outlet unit filtrasi. Perlu disampaikan bahwa tidak dilakukan pengambilan sampel pada outlet flokulasi karena kondisi di lapangan tidak memungkinkan. Pengambilan sampel lumpur juga dilakukan secara grab sampling di ujung pipa pembuangan lumpur unit flokulasi, sedimentasi, dan filtrasi. Pengambilan mulai diambil setelah 30 detik pipa dibuka untuk mendapatkan debit aliran lumpur yang konstan. Selain itu, juga dilakukan pengambilan sampel lumpur selama 8 
hari berturut-turut di muara saluran drainase lumpur sebelum masuk ke sungai. Teknis operasional pengambilan dan pengawetan sampel dilakukan berdasarkan SNI 7828:2012(8) dan SNI $6989: 2008^{(9)}$.

\subsection{Analisis Sampel}

Pada sampel air dilakukan analisis kekeruhan atau turbidity. Kemudian Pada sampel lumpur dilakukan analisis kekeruhan, total solid content (TS), total suspended solids (TSS), volatile suspended solids (VSS), biochemical oxygen demand (BOD), chemical oxygen demand (COD), besi (Fe), aluminium (Al), Total koliform, temperatur, $\mathrm{pH}$, dan specific gravity. Pengujian tersebut dilakukan dengan metode sesuai dengan SNI 6989:2008 ${ }^{(9)}$ dan SNI 1964:2008(10).

\subsection{Pengolahan Data}

\subsubsection{Timbulan Lumpur}

Estimasi timbulan lumpur dapat dilakukan menggunakan dua (2) metode yaitu: (i) secara teoritik dan (ii) secara empirik. Metode teoritik dilakukan berdasarkan rumus perhitungan dari literatur $^{(6)}$ sebagai berikut:

Lumpur dari unit sedimentasi:

$$
\begin{aligned}
& \mathrm{q}_{\text {raw solids }}=\mathrm{C}_{\mathrm{TSS}} \times 10^{-6} \frac{\mathrm{kg}}{\mathrm{mg}} \times 10^{3} \frac{\mathrm{L}}{\mathrm{m}^{3}} \times \mathrm{Q}_{\mathrm{WTP}} \\
& \mathrm{q}_{\mathrm{Fe}}=\mathrm{C}_{\mathrm{Fe}} \times 1.9 \frac{\mathrm{Fe}(\mathrm{OH})_{3}}{\mathrm{Fe}} \times 10^{-6} \frac{\mathrm{kg}}{\mathrm{mg}} \times 10^{3} \frac{\mathrm{L}}{\mathrm{m}^{3}} \times \mathrm{Q}_{\mathrm{WTP}} \\
& \mathrm{q}_{\mathrm{Mn}}=\mathrm{C}_{\mathrm{Mn}} \times 1.6 \frac{\mathrm{MnOOH}}{\mathrm{Mn}} \times 10^{-6} \frac{\mathrm{kg}}{\mathrm{mg}} \times 10^{3} \frac{\mathrm{L}}{\mathrm{m}^{3}} \times \mathrm{Q}_{\mathrm{WTP}} \\
& \mathrm{q}_{\text {coag. }}=\mathrm{C}_{\mathrm{Al} 2(\mathrm{SO} 4) 3} \times 0.26 \frac{\mathrm{Al}(\mathrm{OH})_{3}}{\mathrm{Al}_{2}\left(\mathrm{SO}_{4}\right)_{3}} \times 10^{-3} \frac{\mathrm{kg}}{\mathrm{g}} \times \mathrm{Q}_{\mathrm{WTP}} \\
& \mathrm{q}_{\text {produced }}=\mathrm{q}_{\text {raw solids }}+\mathrm{q}_{\mathrm{Fe}}+\mathrm{q}_{\mathrm{Mn}}+\mathrm{q}_{\mathrm{coag} .} \\
& \mathrm{W}_{\text {sludge clarifier }}=\mathrm{q}_{\mathrm{produced}} \times \eta(5) \\
& \mathrm{Q}_{\text {sludge clarifier }}=\frac{\mathrm{W}_{\text {sludge clarifier }}}{\mathrm{TS} \times \rho} \\
& \text { Lumpur dari backwash unit filtrasi: } \\
& \mathrm{Q}_{\text {sludge filter }}=0.012 \frac{\mathrm{m}}{\mathrm{s}} \times \mathrm{A}_{\mathrm{f}} \times \mathrm{N} \times 60 \frac{\mathrm{s}}{\mathrm{min}} \times \mathrm{t}
\end{aligned}
$$

Estimasi timbulan secara empirik dilakukan berdasarkan pengukuran debit lumpur di lokasi objek studi dengan menggunakan metode float area(11). Prinsip pengukuran metode ini adalah dengan mengukur kecepatan aliran menggunakan pelampung, panjang lintasan, dan luas penampang basah saluran drainase pembuangan lumpur.

$$
\begin{aligned}
& \mathrm{Q}_{\text {sludge }}=0,85 \times \mathrm{A} \times \mathrm{v} \times \mathrm{N} \times 60 \frac{\mathrm{s}}{\min } \times \mathrm{t} \\
& \mathrm{W}_{\text {sludge }}=\mathrm{Q}_{\text {sludge }} \times \mathrm{TS} \times \rho
\end{aligned}
$$

Sehingga total timbulan lumpur alum di suatu IPA dapat dihitung menggunakan persamaan (11) dan (12):

$$
\begin{aligned}
& \mathrm{Q}_{\text {Sludge }}=\mathrm{Q}_{\text {sludge flocculator }}+\mathrm{Q}_{\text {sludge clarifier }}+ \\
& \mathrm{Q}_{\text {sludge filter }} \\
& \mathrm{W}_{\text {Sludge }}=\mathrm{W}_{\text {sludge flocculator }}+\mathrm{W}_{\text {sludge clarifier }}+ \\
& \mathrm{W}_{\text {sludge filter }}
\end{aligned}
$$

\begin{tabular}{|c|c|}
\hline$A_{f}$ & : Luas permukaan media filter $\left(\mathrm{m}^{2}\right)$ \\
\hline $\mathrm{N}$ & : Jumlah unit \\
\hline $\mathrm{t}$ & $\begin{array}{l}\text { : durasi pembuangan lumpur atau } \\
\text { backwash (menit/hari) }\end{array}$ \\
\hline Q & : debit $\left(m^{3} /\right.$ detik $)$ \\
\hline$A$ & $\begin{array}{l}\text { luas penampang basah drainase } \\
\text { lumpur }\left(\mathrm{m}^{2}\right)\end{array}$ \\
\hline $\mathrm{k}$ & : koefisien pelampung $=0,85$ \\
\hline $\mathrm{v}$ & $\begin{array}{l}\text { : kecepatan aliran lumpur di saluran } \\
\text { drainase ( } \mathrm{m} / \text { detik) }\end{array}$ \\
\hline W Sludge $_{\text {S }}$ & : Total produksi lumpur (kg/hari) \\
\hline
\end{tabular}

Keterangan:

qraw solids

qFe

$\mathrm{qMn}_{\mathrm{Mn}}$

qcoag

QWTP

CTSS

$\mathrm{C}_{\mathrm{Fe}}$

$\mathrm{W}_{\text {sludge clarifier }}$

$\eta$

TS

$\rho$

Qsludge filter

\subsubsection{Neraca Massa}

Analisis neraca massa atau mass balance digunakan untuk menghitung kesetimbangan timbulan lumpur (sludge solid loading) dari setiap unit pengolahan di IPA. Analisis ini penting untuk mengevaluasi dan mengkoreksi kesesuaian estimasi timbulan lumpur. Analisis mass balance dilakukan dengan menggunakan software STAN ${ }^{(12)}$. Software STAN (subSTance flow ANalysis) ini berbasiskan pada prinsip material flow analysis (MFA) seperti balance dan stock equation yang umum digunakan untuk analisis pengelolaan lumpur dan limbah ${ }^{(13,14) \text {. }}$

\section{HASIL DAN PEMBAHASAN}

\subsection{Kinerja unit-unit pengolahan}

Kinerja unit-unit pengolahan di IPA diukur dari efisiensi penyisihan (removal) kontaminan terutama penyisihan padatan yang dapat diukur dari parameter seperti kekeruhan, TS atau TSS. Dari hasil sampling di inlet unit koagulasi, outlet unit sedimentasi dan outlet unit filtrasi dapat 
dihitung bahwa removal TSS di unit sedimentasi dan filtrasi berturut-turut sebesar 97,26\% dan $100 \%$ (Tabel 1). Hal tersebut mengindikasikan sekitar $153 \mathrm{mg} / \mathrm{L}$ padatan mengendap di dasar unit sedimentasi dan akan dibuang sebagai lumpur alum, sedangkan sisanya sebesar 4,3 $\mathrm{mg} / \mathrm{L}$ solids akan disisihkan oleh unit filtrasi dan dibuang pada saat proses pencucian (backwash) filter.

\subsection{Karakteristik Lumpur Alum}

Hasil analisis sampel lumpur alum yang diambil dari pipa pembuangan lumpur unit flokulasi, sedimentasi, dan filtrasi dirangkum pada Tabel 2. Berdasarkan data di Tabel 2 dapat dilihat bahwa terdapat beberapa parameter yang melebihi baku mutu lingkungan (BML) Peraturan
Menteri Lingkungan Hidup nomor 5 tahun 2014 tentang baku mutu air limbah bagi usaha dan/atau kegiatan yang belum memiliki baku mutu air limbah yang ditetapkan ${ }^{(15)}$ seperti TSS, COD, Fe, dan total koliform, sehingga jika dibuang langsung berpotensi mencemari sungai. Lebih lanjut, karakteristik lumpur alum di IPA Citayam juga secara umum sesuai dengan literatur $(3,6,11,15)$.

Tabel 1. Efisiensi penyisihan TSS

\begin{tabular}{ccc}
\hline $\begin{array}{c}\text { Titik } \\
\text { Sampling }\end{array}$ & $\begin{array}{c}\text { TSS } \\
(\mathbf{m g} / \mathbf{L})^{*}\end{array}$ & $\begin{array}{c}\text { Removal } \\
\mathbf{( \% )}^{*}\end{array}$ \\
\hline Inlet Koag. & $157,33 \pm 63,89$ & NA \\
Outlet Sed. & $4,33 \pm 4,04$ & $97,26 \pm 3,07$ \\
Outlet Fil. & 0 & 100 \\
\hline \multicolumn{2}{c}{$\left.{ }^{*}\right)$ Berdasarkan tiga kali grab sampling }
\end{tabular}

Tabel 2. Karakteristik lumpur alum

\begin{tabular}{lccccc}
\hline \multicolumn{1}{c}{ Parameter } & Flokulasi & Sedimentasi & Filtrasi & Referensi $^{* * *}$ & BML \\
\hline $\mathrm{pH}$ & 6,92 & 7,5 & 6,94 & $6-9$ & $6-9$ \\
Suhu $\left({ }^{\circ} \mathrm{C}\right)$ & 25 & 25 & 25 & - & 38 \\
Kekeruhan (NTU) & 251 & $\mathrm{H}^{* *}$ & 493 & - & - \\
$\mathrm{TS}(\%)$ & 0,025 & 2,29 & 0,059 & $0,1-4$ & - \\
$\mathrm{TSS}(\mathrm{mg} / \mathrm{L})$ & 100 & $37.720^{*}$ & $1.170^{*}$ & $2.910-39.000$ & 200 \\
$\mathrm{VSS}(\mathrm{mg} / \mathrm{l})$ & 900 & 4.720 & 980 & $1.570-12.700$ & - \\
$\mathrm{BOD}(\mathrm{mg} / \mathrm{l})$ & 1,56 & 4,74 & 3,16 & $13-300$ & 50 \\
$\mathrm{COD}(\mathrm{mg} / \mathrm{l})$ & 11 & $3.750^{*}$ & $650^{*}$ & $30-5.000$ & 100 \\
$\mathrm{Fe}(\mathrm{mg} / \mathrm{l})$ & 0,1 & $16,5^{*}$ & 2,86 & $8-515$ & 5 \\
$\mathrm{Al}(\mathrm{mg} / \mathrm{l})$ & 5,05 & 159,73 & 61,08 & $15-1.194$ & - \\
Total Koliform & 2.200 & $640.000^{*}$ & $22.000^{*}$ & - & 10.000 \\
\hline
\end{tabular}

$\left({ }^{*}\right)$ melebihi BML PermenLH No. 5 tahun 2014; $\left({ }^{* *}\right)$ Konsentrasi melebihi limit deteksi; $\left({ }^{* \star *}\right)$ Referensi 3,15$)$

Untuk mengetahui fluktuasi karakteristik lumpur alum, dilakukan juga pengambilan sampel dari unit sedimentasi selama 8 hari dan disajikan dalam Gambar 1. Berdasarkan data tersebut dapat dilihat rata-rata konsentrasi TSS pada lumpur alum sebesar $34.410 \mathrm{mg} / \mathrm{L}$ dengan deviasi konsentrasi $5,8 \%$. Namun perlu dicatat bahwa konsentrasi TSS pada lumpur alum sangat dipengaruhi oleh karakteristik air baku (Sungai Ciliwung) terutama konsentrasi padatan serta pada tingkat pengaruh yang lebih rendah oleh konsentrasi besi, mangan dan dosis koagulan.

Oleh karena itu tren kualitas air baku juga dikaji menggunakan data sekunder milik PDAM Tirta Asasta (Gambar 2). Berdasarkan Gambar 2 dapat disimpulkan bahwa konsentrasi kekeruhan di air baku ada di kisaran 70,3 NTU dengan deviasi $\pm 8,46$ NTU atau $12,04 \%$. Lebih lanjut untuk konsentrasi besi dan mangan berturutturut ada pada rentang konsentrasi $0,3+0,117$ $\mathrm{mg} / \mathrm{L}$ dan $0,05 \pm 0,021 \mathrm{mg} / \mathrm{L}$. Sedangkan untuk dosis koagulan tidak terdapat pencatatan rutin namun dari hasil wawancara dengan operator IPA Citayam dosis koagulan alum sulfat umumnya sekitar $27 \mathrm{~g} / \mathrm{m}^{3}$. Dosis koagulan umumnya bervariasi tergantung karakteristik air baku yang diolah terutama parameter kekeruhan. Namun dosis rata-rata $27 \mathrm{~g} / \mathrm{m}^{3}$ yang digunakan IPA Citayam masih sesuai dengan tipikal dosis koagulan yang umum digunakan di PDAM (sekitar 20-40 $\left.\mathrm{g} / \mathrm{m}^{3}\right)^{(11,16)}$ dan kriteria desain (antara 10-150 $\left.\mathrm{g} / \mathrm{m}^{3}\right)^{(3)}$.

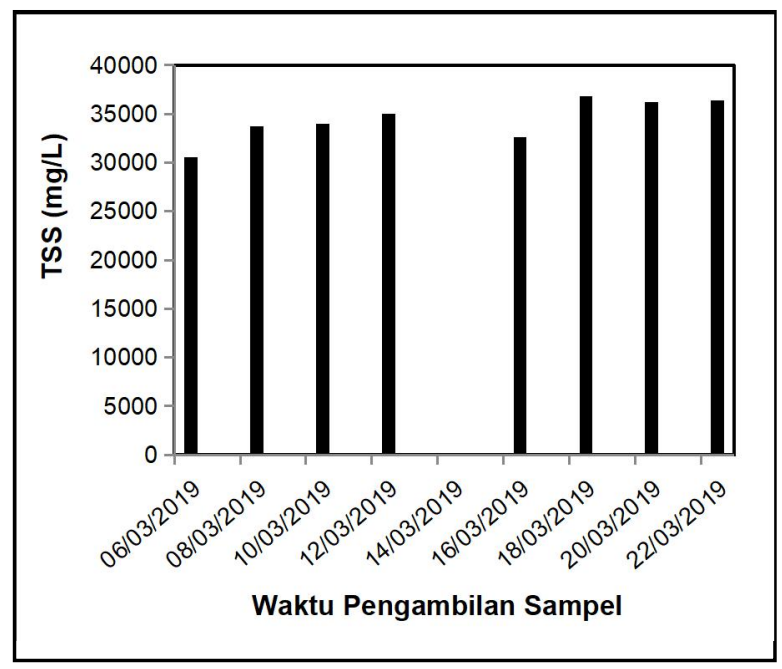

Gambar 1. Fluktuasi TSS pada lumpur alum 


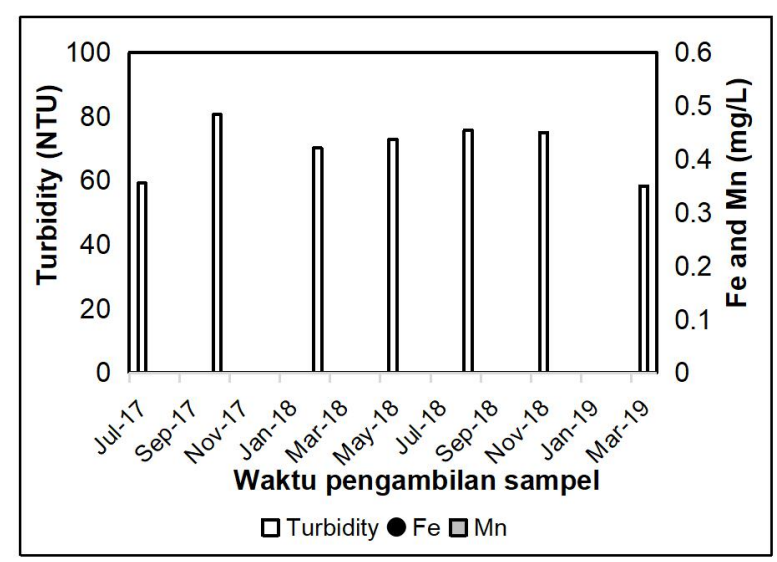

Gambar 2. Fluktuasi kekeruhan, $\mathrm{Fe}, \mathrm{Mn}$ pada air baku

\subsection{Estimasi Timbulan Lumpur}

Merujuk kembali pada sub-bab 2.5.1, estimasi timbulan lumpur alum secara teoritik dapat dihitung berdasarkan total timbulan lumpur alum yang dihasilkan oleh unit sedimentasi dan filtrasi. Sedangkan lumpur alum yang dihasilkan dari unit flokulasi umumnya diabaikan. Hal ini karena kuantitasnya tidak signifikan. Timbulan lumpur alum dari unit sedimentasi dihitung dengan Persamaan (1) sampai (7) dengan mengacu pada data berikut: QwTP $=10.368$ $\mathrm{m}^{3} / \mathrm{hari} ; \quad \mathrm{C}_{\mathrm{TSS}}=157,33 \mathrm{mg} / \mathrm{L} ; \mathrm{C}_{\mathrm{Fe}}=0,3 \mathrm{mg} / \mathrm{L}$; $\mathrm{C}_{\mathrm{Mn}}=0,05 \quad \mathrm{mg} / \mathrm{L} ; \quad \mathrm{C}_{\text {coag }}=27 \quad \mathrm{~g} / \mathrm{m}^{3} ; \quad \eta=97,26 \%$; TS $=2,29 \%$ dan $\rho=1.011 \quad \mathrm{~kg} / \mathrm{m}^{3}$, sehingga diperoleh timbulan lumpur alum dari unit sedimentasi sebesar $1.664 \mathrm{~kg} / \mathrm{hari}$ atau 71,87 $\mathrm{m}^{3} /$ hari.

Untuk unit filtrasi, timbulan lumpur alum berasal dari kegiatan pencucian (backwash) dapat dihitung dengan persamaan (8) dengan mengacu pada data-data berikut: $A_{f}=9,2 \mathrm{~m}^{2} ; \mathrm{N}_{\mathrm{f}}=6$ unit, $\mathrm{t}=5$ menit; TS $=0,117 \%$ dan $\rho=1.000 \mathrm{~kg} / \mathrm{m}^{3}$, sehingga diperoleh timbulan lumpur alum dari unit filtrasi sebesar $233 \mathrm{~kg} / \mathrm{hari}$ atau $199 \mathrm{~m}^{3} /$ hari.

Sebagai perbandingan, dilakukan juga estimasi timbulan lumpur alum berdasarkan pengukuran langsung dilapangan menggunakan metode float area. Berdasarkan Persamaan (9), data-data yang dibutuhkan untuk estimasi timbulan lumpur dengan metode tersebut adalah luas penampang saluran $(A)$, kecepatan aliran lumpur alum di saluran drainase (v), jumlah unit atau kompartemen $(\mathrm{N})$, dan durasi pembuangan lumpur (t). Berdasarkan hasil survei dan wawancara diperoleh data drainase lumpur alum setiap unit sebagai berikut:

(i) unit flokulasi: $A=0,54 \mathrm{~m}^{2} ; \mathrm{v}=0,51 \mathrm{~m} / \mathrm{s} ; \mathrm{N}=6$ kompartemen; $t=1$ menit

(ii) unit sedimentasi: $A=0,54 \mathrm{~m}^{2} ; \mathrm{v}=0,67 \mathrm{~m} / \mathrm{s}$; $\mathrm{N}=2$ unit; $\mathrm{t}=5$ menit

(iii) unit filtrasi: $A=0,54 \mathrm{~m}^{2} ; \mathrm{v}=0,58 \mathrm{~m} / \mathrm{s} ; \mathrm{N}=6$ unit; $\mathrm{t}=5$ menit

Dengan menggunakan data diatas dan persamaan (9) dan (10), maka timbulan lumpur alum dari unit flokulasi, sedimentasi, dan filtrasi berturut-turut adalah $21,07 \mathrm{~kg} / \mathrm{hari} \quad(84,27$ $\mathrm{m}^{3} /$ hari), $4.272 \mathrm{~kg} /$ hari $\left(184,52 \mathrm{~m}^{3} /\right.$ hari), dan $560,66 \mathrm{~kg} /$ hari $\left(479,20 \mathrm{~m}^{3} /\right.$ hari $)$. Rekapitulasi hasil perhitungan dirangkum di Tabel 3. Dapat dilihat bahwa estimasi timbulan lumpur alum dengan metode empirik tiga kali lebih besar daripada teoritik. Perbedaan ini dapat diakibatkan oleh beberapa hal, pertama, pada metode teoritik tidak mempertimbangkan timbulan lumpur alum dari unit flokulasi karena pada prinsipnya unit flokulasi memang tidak didesain untuk mengendapkan kontaminan. Kedua, metode empirik perhitungan berbasiskan pada prosedur operasional riil harian IPA Citayam seperti durasi pengurasan, yang mungkin tidak akurat.

Untuk mempermudah perbandingkan antar IPA dengan kapasitas berbeda, timbulan lumpur umumnya dinyatakan dalam bentuk (i) rasio $\mathrm{kg}$ timbulan lumpur per $1.000 \mathrm{~m}^{3}$ air baku yang diolah atau (ii) prosentase debit timbulan lumpur per kapasitas produksi. Mengacu pada literatur, timbulan lumpur umumnya berkisar antara 8-210 $\mathrm{kg} / 1.000 \mathrm{~m}^{3}$ atau $2-5 \%{ }^{(3,6)}$, sehingga hasil perhitungan dengan metode teoritik $\left(183 \mathrm{~kg} / \mathrm{m}^{3}\right.$ atau $3 \%$ ) yang cenderung lebih tepat.

Tabel 3. Timbulan lumpur alum

\begin{tabular}{|c|c|c|c|c|}
\hline \multirow[t]{3}{*}{ Unit } & \multicolumn{4}{|c|}{ Timbulan lumpur alum } \\
\hline & \multicolumn{2}{|c|}{ Teoritik } & \multicolumn{2}{|c|}{ Empirik } \\
\hline & (kg/hari) & (m³/hari) & (kg/hari) & (m³/hari) \\
\hline Flokulasi & 0 & 0 & 21,07 & 84,27 \\
\hline Sedimentasi & 1.664 & 71,87 & 4.272 & 184,5 \\
\hline Filtrasi & 233,5 & 198,7 & 560,7 & 479,2 \\
\hline Total & 1.898 & 271 & 4.854 & 748 \\
\hline \multicolumn{5}{|c|}{ Rasio terhadap air baku yang diolah } \\
\hline kg per $1.000 \mathrm{~m}^{3}$ & \multicolumn{2}{|c|}{183} & \multicolumn{2}{|c|}{468} \\
\hline dalam persen $(\%)$ & \multicolumn{2}{|c|}{3} & \multicolumn{2}{|c|}{7} \\
\hline
\end{tabular}




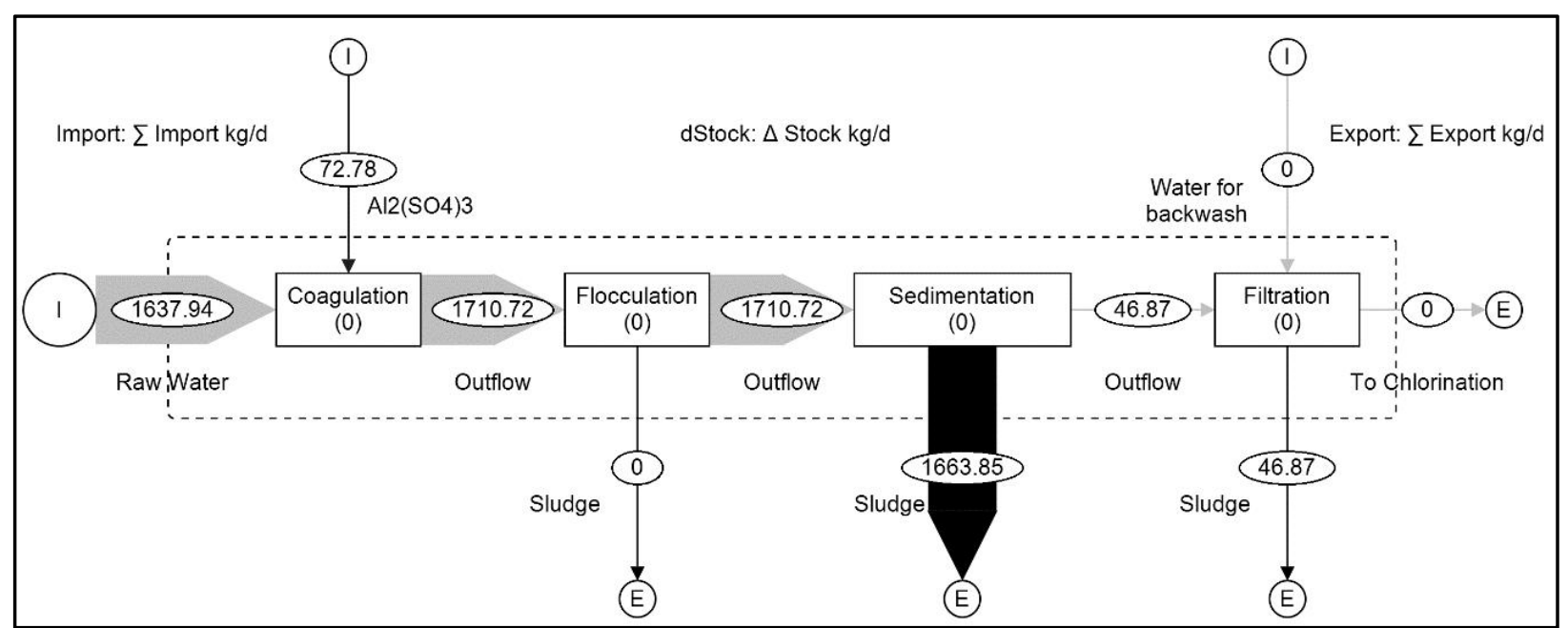

Gambar 3. Neraca massa TS dari hasil estimasi timbulan lumpur alum secara teoritik

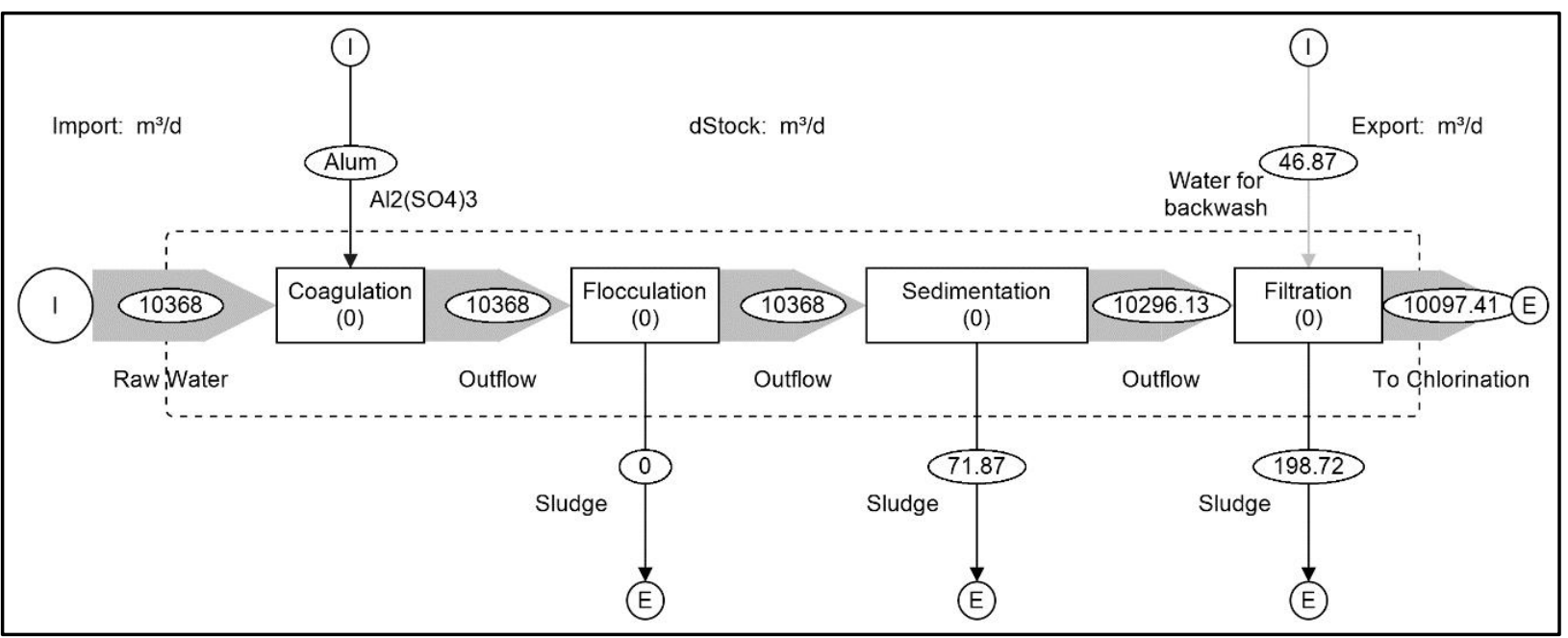

Gambar 4. Neraca volume dari hasil estimasi timbulan lumpur alum secara teoritik

\subsection{Analisis Neraca Massa Lumpur Alum}

Data inflow, outflow, dan timbulan lumpur alum dari unit koagulasi, flokulasi, sedimentasi, dan filtrasi dapat digunakan sebagai dasar acuan dalam analisis neraca lumpur (massa TS dan debit). Analisis dilakukan dengan bantuan software STAN dan hasilnya dapat dilihat pada Gambar 3 dan 4. Hasil analisis neraca massa timbulan lumpur dengan metode teoritik (Gambar 3) menunjukan timbulan lumpur paling besar berasal dari unit sedimentasi yaitu sekitar 1.664 $\mathrm{kg} / \mathrm{hari}$ atau 608 ton/tahun. Sedangkan untuk unit flokulasi diasumsikan tidak ada pembuangan lumpur. Dengan model teoritik ini tidak ada stock atau akumulasi lumpur karena diasumsikan pembuangan lumpur rutin dilakukan setiap hari.

Di sisi lain, hasil analisis neraca massa dan debit untuk model empirik (Gambar 5 dan 6) menunjukan akumulasi lumpur alum sebesar
$-2.628,59 \mathrm{~kg} / \mathrm{hari}$ di dua unit sedimentasi $(-1.314,29 \mathrm{~kg} / \mathrm{hari} / \mathrm{unit})$ serta $-236,43 \mathrm{~kg} /$ hari di enam unit filter $(-39.41 \mathrm{~kg} / \mathrm{hari} / \mathrm{unit})$. Nilai stok negatif ini disebabkan oleh over-estimasi timbulan massa lumpur yang dibuang dari unit sedimentasi dan filtrasi. Over-estimasi tersebut dapat dijelaskan dengan dua hal yaitu (i) overestimasi akibat konsentrasi TS yang diukur pada sampel lumpur, karena sampel diambil hanya beberapa saat setelah katup pipa lumpur dibuka sehingga konsentrasi TS masih sangat tinggi; dan/atau (ii) over-estimasi durasi pengurasan lumpur yaitu waktu pengurasan yang terlalu lama sehingga air olahan di dalam unit sedimentasi juga ikut terbuang. Jika melihat hasil perhitungan teoritik, durasi pengurasan lumpur berpotensi dikurangi 2,5 kali $(4.272 / 1.664=2,5)$ dari 5 menit menjadi 2 menit. Namun implementasinya tetap perlu berdasarkan uji coba langsung di lokasi. 


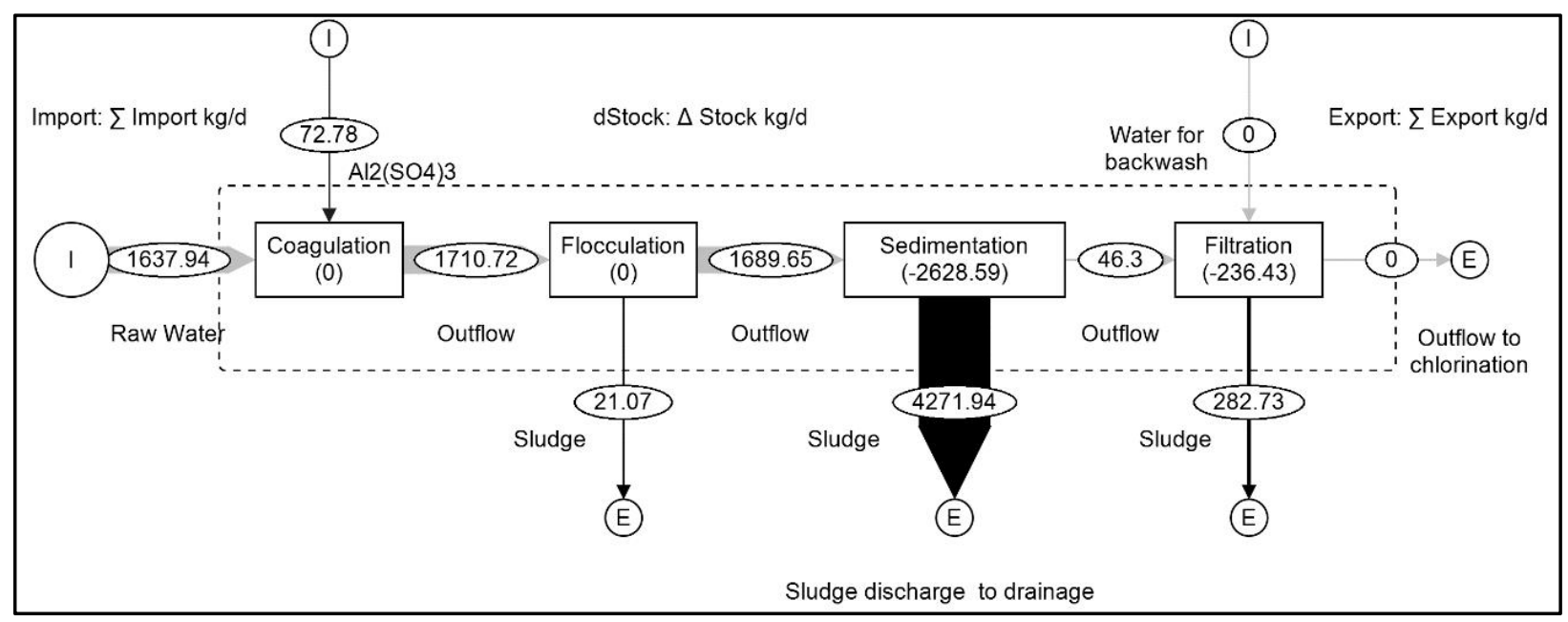

Gambar 5. Neraca massa TS dari hasil estimasi timbulan lumpur alum secara empirik

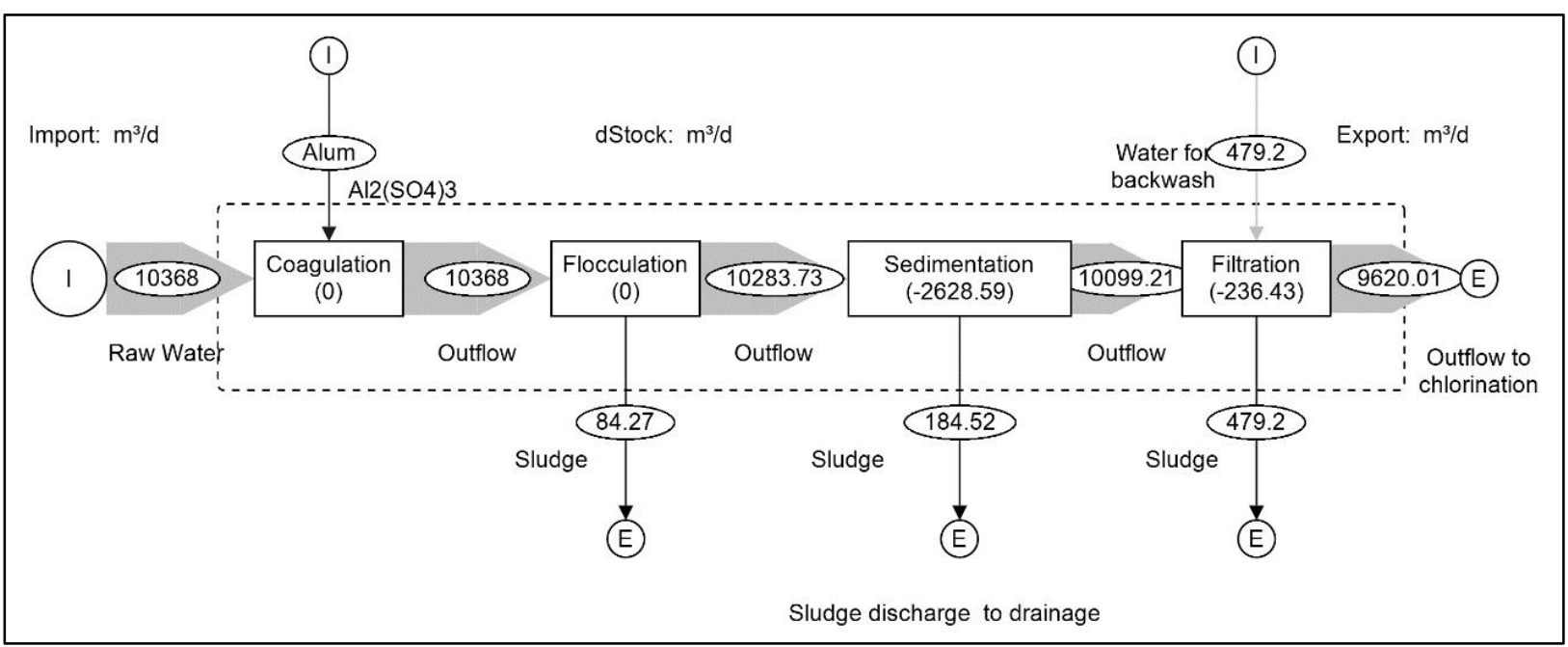

Gambar 6. Neraca volume dari hasil estimasi timbulan lumpur alum secara empirik

\section{KESIMPULAN}

Evaluasi karakteristik lumpur alum di IPA Citayam telah dilakukan. IPA Citayam menghasilkan lumpur alum dari pipa pembuangan lumpur pada unit flokulasi, sedimentasi dan pencucian filter. Dari aspek kualitas, lumpur alum dari unit sedimentasi dan filtrasi melebihi baku mutu lingkungan Peraturan Menteri Lingkungan Hidup nomor 5 tahun 2014 untuk parameter TSS, COD, dan Total Koliform. Dari aspek kuantitas, estimasi total timbulan lumpur dengan metode teoritik sebesar $183 \mathrm{~kg}$ lumpur per $1.000 \mathrm{~m}^{3}$ air baku yang diolah (1.898 $\mathrm{kg} /$ hari), sedangkan untuk metode empirik menunjukan hasil yang lebih besar yaitu $468 \mathrm{~kg}$ lumpur per $1.000 \mathrm{~m}^{3}$ air baku yang diolah (4.854 $\mathrm{kg} / \mathrm{hari})$. Analisis neraca massa TS dan volume mengindikasikan potensi peningkatan produksi air melalui pengurangan durasi pengurasan unit sedimentasi. Penelitian aplikatif terkait lanjutan perlu dilakukan untuk perancangan sistem pengolahan lumpur yang tepat guna.

\section{PERSANTUNAN}

Penulis mengucapkan terima kasih kepada RISTEKDIKTI atas hibah penelitian PDUPT (nomor kontrak: NKB-1633/UN2.R3.1/ HKP.05.00/2019). Penulis juga mengucapkan terima kasih kepada PDAM Tirta Asasta, Perusahaan Daerah Air Minum Kota Depok karena menyediakan lokasi objek studi. Tidak lupa penulis juga ingin mengapresiasi Laboratorium Teknik Penyehatan dan Lingkungan Universitas Indonesia atas dukungannya untuk kegiatan analisis sampel.

\section{DAFTAR PUSTAKA}

1. Keeley, J., Jarvis, P., \& Judd, S. J. (2014). Coagulant recovery from water treatment residuals: a review of applicable technologies. Critical Reviews in Environmental Science and Technology, 44(24), 2675-2719. 
2. Gomes, S. D. C., Zhou, J. L., Li, W., \& Long, G. (2019). Progress in manufacture and properties of construction materials incorporating water treatment sludge: A review. Resources, Conservation and Recycling, 145, 148-159.

3. Crittenden, J. C., Trussell, R. R., Hand, D. W., Howe, K. J., \& Tchobanoglous, G. (2012). MWH's water treatment: principles and design. John Wiley \& Sons.

4. Hou, X., Feng, L., Duan, H., Chen, X., Sun, D. \& Shi, K. (2017). Fifteen-year monitoring of the turbidity dynamics in large lakes and reservoirs in the middle and lower basin of the Yangtze River, China. Remote Sensing of Environment, 190, 107-121.

5. Yang, Z., Gao, B., \& Yue, Q. (2010). Coagulation performance and residual aluminum speciation of $\mathrm{Al} 2$ (SO4) 3 and polyaluminum chloride (PAC) in Yellow River water treatment. Chemical Engineering Journal, 165(1), 122-132.

6. Qasim, S. R., Motley, E. M., \& Zhu, G. (2000). Water works engineering: planning, design, and operation. Prentice Hall.

7. Kementerian Pekerjaan Umum dan Perumahan Rakyat. (2015). Sejarah Air Minum Indonesia. Jakarta: PUPR

8. Badan Standardisasi Nasional. (2012). SNI 7828:2012 Tentang Kualitas Air-Pengambilan Contoh-Bagian 5: Pengambilan Contoh Air Minum dari Instalasi Pengolahan Air dan Sistem Jaringan Distribusi Perpipaan, Indonesia.

9. Badan Standardisasi Nasional. (2008). SNI 6989:2008 Tentang Air dan Air Limbah.
10.Badan Standardisasi Nasional. (2008). SNI 1964:2008 Tentang Cara Uji Berat Jenis Tanah.

11. Adityosulindro, S., Hartono, D. J., \& Pramusinto, A. C. (2013). Evaluasi timbulan lumpur dan perancangan sistem pengolahan lumpur (studi kasus: Instalasi Pengolahan Air Minum Cibinong, Jawa Barat). Lingkungan Tropis, 7(2), 131-146.

12. Technishe Universitat Wien (TU Wien). (2012). STAN (short for subSTance flow ANalysis) Software. http://www.stan2web.net/.

13. Cencic, O. (2016). Nonlinear data reconciliation in material flow analysis with software STAN. Sustainable Environment Research, 26(6), 291-298.

14. Fisher, R. M., Alvarez-Gaitan, J. P., Stuetz, R. M., \& Moore, S. J. (2017). Sulfur flows and biosolids processing: using Material Flux Analysis (MFA) principles at wastewater treatment plants. Journal of environmental management, 198, 153-162.

15. Kementerian Lingkungan Hidup. (2014). Peraturan Menteri Lingkungan Hidup Nomor 5 Tahun 2014.

16. Barakwan, R. A., Trihadiningrum, Y., \& Bagastyo, A. Y. (2019). Characterization of alum sludge from surabaya water treatment plant, Indonesia. Journal of Ecological Engineering, 20(5), 7-13.

17.Zahra, S. A. (2014). Karakteristik Kualitas Air Baku \& Lumpur sebagai Dasar Perencanaan Instalasi Pengolahan Lumpur IPA Badak Singa PDAM Tirtawening Kota Bandung. REKA LINGKUNGAN, 2(2), 1-10. 